\title{
Low Cost Management Practices to Detect and Control Sub-Clinical Mastitis in Dairy Cattle
}

\author{
Tripti Kumari*, Champak Bhakat, Amit Kumar Singh, Jyotimala Sahu, \\ D.K. Mandal and R.K. Choudhary \\ ICAR-Eastern Regional Station, National Dairy Research Institute, \\ Kalyani - 741235, West Bengal, India \\ *Corresponding author
}

A B S T R A C T

\begin{tabular}{|l|}
\hline Ke y w or d s \\
Sub clinical \\
Mastitis, Tri sodium \\
citrate, Surf field \\
mastitis test, Dairy \\
cows
\end{tabular}

\section{Keywords}

\section{Introduction}

Mastitis causes severe economic losses to the dairy farmers throughout the world. Mastitis cause annual losses of about USD 153 million (Rs.72 billion) in India as per 2009 estimates (Bansal \& Gupta, 2009), 60\% of which are due to the sub-clinical form. Since there is hardly any discernible change in the udder or in the milk, the farmer usually remains unaware of the existence of this form in their
Sub clinical mastitis is a hidden form of mastitis, causes a huge economical loss to the farmers. So, present study was done with the aim to find out such management practice to detect and control sub-clinical mastitis in the dairy cattle under field condition that can easily be adopted by the farmers. Eighty cattle having sub clinical mastitis were selected by Surf Field Mastitis Test (SFMT) and divided into two groups i.e., control $(\mathrm{N}=40)$ and treatment $(\mathrm{N}=40)$. Tri sodium citrate @ $30 \mathrm{mg} / \mathrm{kg}$ body wt. was supplemented to the cows orally till 10 days in the treatment group. Milk sample was collected at 0 and after 10 day of the experimental period and analysed for somatic cell count (SCC), milk pH, electrical conductivity (EC), milk yield (kg), fat, SNF, protein and lactose \%. It was found that recovered rate from SCM, milk yield, fat, SNF, protein and lactose were high and SFMT score, milk SCC, $\mathrm{pH}$ and EC were low in the treatment group of the cows. Hence, detection of SCM through SFMT and control by use of tri-sodium citrate is an effective, easy and cost-effective management practices which will support the farmers in raising their income through increase in milk quality and quantity. 
of 80.5 million in-milk animals i.e., cattle and buffalo (19th Livestock Census, 2012) with its thin distribution poses significant challenges in implementation of a control programme in the field. Covering such a large population would be very difficult if one has to reach out to individual farmers directly. The control programme should be focused on detection and management of mastitis. Controlling SCM will play a central role that will have a cascading effect of reducing the production losses and decreasing the number of clinical and chronic mastitis cases. The farmers also need to be equipped with simple testing methods to periodically test their animals for SCM. Once SCM positive animals are identified in the field, it is imperative that cost-effective, easily executable solutions are provided to the farmers.

There are several diagnostic tests for detection of SCM. Among the simplest tests, Surf field mastitis test (SFMT) are arguably one of the reliable cow side screening tests for SCM, which do not require any complex laboratory equipment, are solutions containing detergents (Sargeant et al., 2001). It is inexpensive, rapid and can easily be applied.

As it has been reported that mastitic milk are low in citrate level (Dhillon and Singh, 2009). Citrate plays a crucial role in the lactogenesis and maintains udder health through ionic equilibration (Hyvonen et al., 2010). It was hypothesized that replenishment of citrate deficiency with extraneous tri sodium citrate (TSC) might play some protective role against sub clinical mastitis. Feeding citrate orally to the mastitic animals led to an increase in milk citrate levels and helped in improving clinical condition of animals (Renu et al., 2016). TSC administration increased the fat, S.N.F and milk yield over the respective values in mastitic milk (Prakash et al., 2013). The oral regimen of TSC was thus thought to be good practices for field testing. Hence, the aim of the present study was to develop low cost management practices for detection and control of sub clinical mastitis in the dairy cattle, so that farmers can easily adopt it.

\section{Materials and Methods}

The study was done under field condition. Eighty lactating cows suffering from SCM were selected at the surrounding villages of Kalyani, Nadia district, West Bengal, India. SCM was detected through Surf Field Mastitis Test (SFMT). The experimental animals were divided into two groups, viz. control and treatment groups. Under treatment group lactating cows were supplemented TSC (a) $30 \mathrm{mg} / \mathrm{kg}$ body wt. orally till 10 days, whereas in control group no supplementation was given to the animals. Tri-sodium citrate was supplemented orally with feed once a day. Milk sample was collected at 0 day and after 10 days from both groups of the experimental animals. Daily milk yield (morning and afternoon) was noted. Milk samples were tested for somatic cell count (SCC), electrical conductivity (EC), pH, Surf Field Mastitis Test (SFMT), milk fat, SNF, protein and lactose. Statistical analyses of data were done by one-way ANOVA with SPSS 20 package software.

\section{Results and Discussion}

\section{Recovery rate}

From table 1, it is evident that in control group among 40 cows, none have recovered, whereas in the treatment group, 38 out of 40 (95\%) cows have recovered from SCM. Similar findings were suggested by Sarfaraz et al., (2009) and Sripad (2013) who also found that oral administration of tri sodium citrate cures sub clinical mastitis in buffaloes $(69.2 \%)$ and cows (62.5\%) respectively. 
Prakash et al., (2010) observed that once a day injection of tri-sodium citrate together with trimethoprim intra venously for 7 days should cure mastitis powerfully in dairy cows. Reddy et al., 2017 are also in agreement with the present findings that the percentage cure after second screening and treatment with 10 gms coated Tri sodium for 10days is highly significant offering on-label solutions for success of sub clinical mastitis treatment.

\section{Surf Field Mastitis Test (SFMT)}

Total 80 lactating cows were screened out on the basis of SCC, EC, pH and SFMT. All the animals were found positive for SCM through SFMT. All the diagnostic tests were found significant between control and treatment groups $(\mathrm{P}<0.01)$ (Table 2$)$. Score value was found lower in treatment group $(0.44 \pm 0.02)$ which indicates that animals were free from SCM as compare to control group (4.12 \pm 0.03) (Fig. 1).

\section{Somatic Cell Count (SCC)}

There was a significant difference in SCC (X $10^{5}$ cells $\left./ \mathrm{ml}\right)$ between the two groups $(\mathrm{P}<$ 0.01) (Table 2). Somatic cell was found highest in the control $\left(5.1 \times 10^{5}\right.$ cells $\left./ \mathrm{ml}\right)$ than treatment $\left(0.47 \times 10^{5}\right.$ cells $\left./ \mathrm{ml}\right)$ group (Fig. 1). Highest SCC was observed on the day before tri sodium citrate supplementation and lowest SCC was found after 10th day of supplementation. This was in agreement with the findings of Dhillon et al., (1997) and Mbonwanayo et al., (2017).

\section{Milk Electrical Conductivity (EC)}

Significant differences in mean milk EC $(\mathrm{mS} / \mathrm{cm})$ was found between control and treatment groups $(\mathrm{P}<0.01)$ (Table 2$)$. EC was found to be higher in control $(5.67 \pm 0.03)$ than treatment group $(4.52 \pm 0.02)$ (Fig. 1). Norberg et al., (19) explained that the mean
EC of healthy cows was $4.87 \mathrm{mS} / \mathrm{cm}$, while the mean EC of SCM cow was $5.37 \mathrm{mS} / \mathrm{cm}$. Similar finding was reported by Ilie et al., (2010), who mentioned that for the sub clinically infected quarters $(\mathrm{n}=115)$, the mean EC was $5.42 \mathrm{mS} / \mathrm{cm}$, while it was 4.53 $\mathrm{mS} / \mathrm{cm}$ for the healthy $(\mathrm{n}=21)$. According to the researchers finding (Norberg et al., 1997 and Janzekovi et al., 2009), electrical conductivity is an indicator of subclinical mastitis when it is above $>5.5 \mathrm{mS} / \mathrm{cm}$. This increase in EC value results from the alteration of the concentration of mineral substances.

\section{Milk pH}

Milk $\mathrm{pH}$ was found significant statistically ( $\mathrm{P}$ $<0.01$ ) between two groups (Table 2). It was recorded higher in in control $(6.85 \pm 0.02)$ than treatment $(6.42 \pm 0.01)$ group (Fig. 1). The cases were treated with trisodium citrate and $\mathrm{pH}$ of milk was found normal after supplementation. Previously, Dhillon et al., (1989) observed that chemotherapeutic treatment of mastitis has not been successful to desirable extent. Since normal milk $\mathrm{pH}$ is considered unsuitable for the growth of common bacterial pathogens and mastitic milk has an alkaline $\mathrm{pH}$. Hence it creates unfavourable $\mathrm{pH}$ medium in the quarter/udder retarding the infection. It was hypothesized that administration of trisodium citrate orally might correct/optimize milk pH. Prakash and Sharma (1994) also recorded a gradual decrease in milk $\mathrm{pH}$ after the trisodium citrate and oral therapy.

\section{Milk yield}

There were significant $(\mathrm{P}<0.01)$ differences in mean milk yield $(\mathrm{kg})$ between two groups (Table 2). It was found higher in treatment $(3.10 \pm 0.34)$ as compare to control $(2.50 \pm$ 0.33). Similar finding was reported by Prakash et al., (2013). The rise in milk yield 
in the animals, suffering from mastitis may be explained keeping in view the role of citrate in the synthesis and secretion of milk. Fleet $e t$ al., (1975) called milk citrate a harbinger of lactogenesis. Moreover, restoration of trisodium citrate in animals suffering from mastitis decreases $\mathrm{pH}$ of milk and perhaps acts against $\mathrm{Ca}++$ injury and reduces the inflammatory process in the quarters of the udder, which in turn makes mammary secretary cells more efficient and ultimately the milk yield is increased.

\section{Milk fat}

Milk fat (\%) was found less in the control group as compared to treatment group. In the market, fat percentage is indicative of quality of milk. In control group, fat percentage was recorded $2.53 \pm 0.03$ and after treatment with Tri sodium citrate, it was found to increase $3.22 \pm 0.04$ in treatment group (Table 2). It is in close agreement with Singh et al., (1997) and Prakash et al., (2013) who also observed that fat content of milk in sub-clinically infected quarters were reduced against normal value. The increment in fat was spectacular (190\%) because citrate plays an indirect role through NADPH in de novo synthesis of fatty acids in the mammary gland (Garnsworthy et al., 2006).

\section{Milk Solid Not Fat (SNF)}

Table 2 shows that the milk $\mathrm{SNF}(\%)$ was below the normal range in control group and it was observed $7.79 \pm 0.04$, whereas in treatment group it was respectively higher i.e., $8.45 \pm 0.05$. Similar finding was reported by Ashworth et al., (1967) and Prakash et al., (2013). The variation found might be due to decrease in lactose content of mastitic milk because milk lactose and protein are the major constituents of SNF.

Table.1 Recovery rate from sub clinical mastitis in two experimental groups of dairy cows

\begin{tabular}{|c|c|c|c|}
\hline Groups & No. of affected animals & No. of recovered animals & \% of recovered animals \\
\hline Control & 40 & 0 & 0 \\
\hline Treatment & 40 & 38 & 95 \\
\hline
\end{tabular}

Table.2 Mean \pm S.E. of several milk parameters in two experimental groups of dairy cows

\begin{tabular}{|c|c|c|}
\hline & Control & Treatment \\
\hline Milk Parameters & $4.10 \pm 0.22^{\mathrm{a}}$ & $0.47 \pm 0.01^{\mathrm{b}}$ \\
\hline SCC (x105 cells/ml) & $6.85 \pm 0.02^{\mathrm{a}}$ & $6.42 \pm 0.01^{\mathrm{b}}$ \\
\hline pH & $5.67 \pm 0.03^{\mathrm{a}}$ & $4.52 \pm 0.02^{\mathrm{b}}$ \\
\hline EC (mS/cm) & $0.24 \pm 0.02^{\mathrm{a}}$ & $3.12 \pm 0.03^{\mathrm{b}}$ \\
\hline SFMT (score) & $3.10 \pm 0.34^{\mathrm{a}}$ & $2.50 \pm 0.33^{\mathrm{b}}$ \\
\hline Milk Yield (kg/day) & $2.53 \pm 0.03^{\mathrm{a}}$ & $3.22 \pm 0.04^{\mathrm{b}}$ \\
\hline Milk Fat (\%) & $7.79 \pm 0.04^{\mathrm{a}}$ & $8.45 \pm 0.05^{\mathrm{b}}$ \\
\hline Milk SNF (\%) & $3.46 \pm 0.36$ & $3.55 \pm 0.37$ \\
\hline Milk Protein (\%) & $2.25 \pm 0.12^{\mathrm{a}}$ & $3.75 \pm 0.04^{\mathrm{b}}$ \\
\hline Milk Lactose (\%) & & \\
\hline
\end{tabular}

Means having different superscripts within the same row differs significantly $(\mathrm{P}<0.01)$ 
Fig.1 Different milk tests in two experimental groups of dairy cows

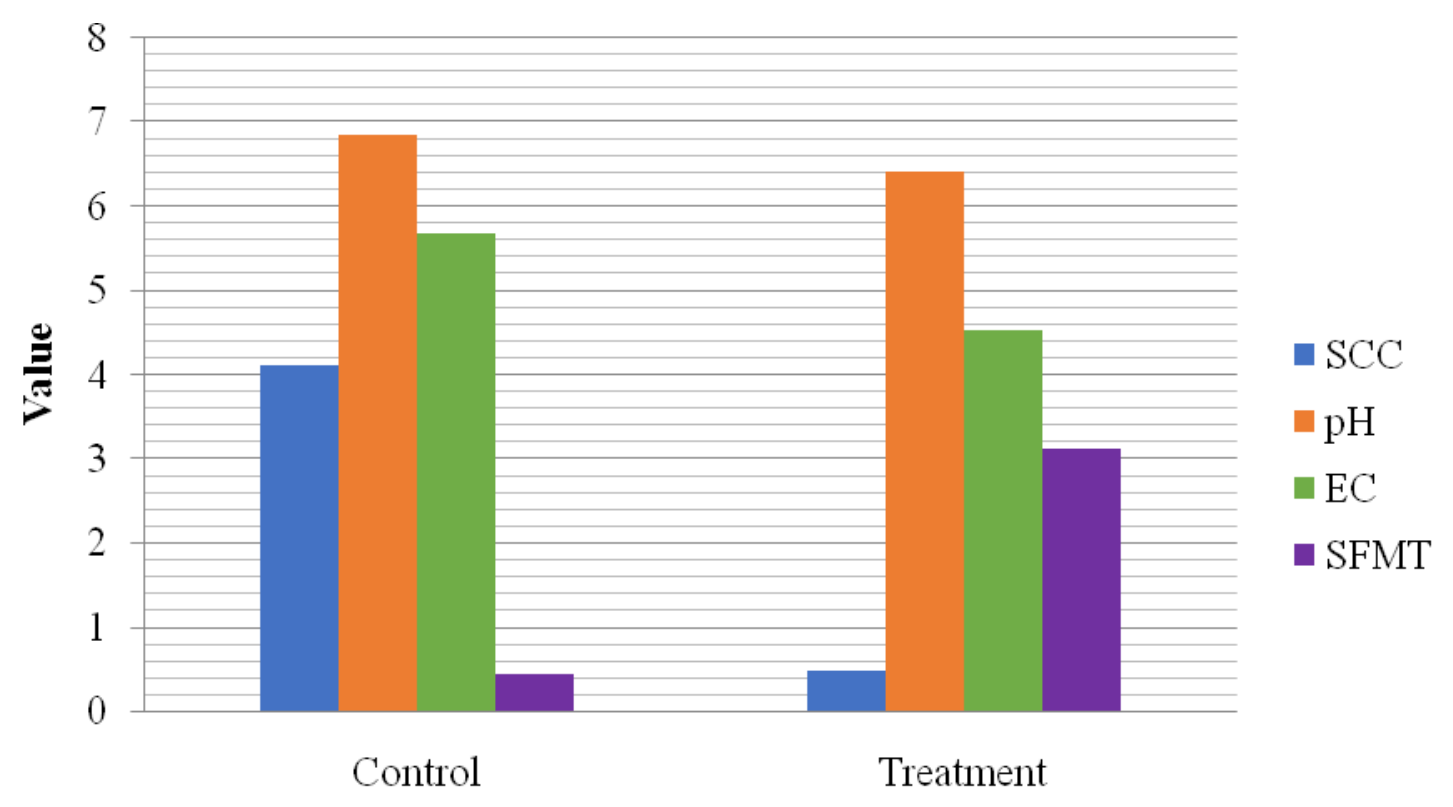

Groups

\section{Milk protein}

Milk protein (\%) was found to be nonsignificant between the two groups $(\mathrm{P}>0.01)$ (Table 2). Contrary to the present finding was reported by Mbonwanayo et al., (2016), who found variation in the milk protein (\%) among the sampling days during the trial period.

\section{Milk lactose}

Milk lactose (\%) was found to be significant statistically $(\mathrm{P}<0.01)$ (Table 2$)$. There was low percentage of milk lactose in the control $(2.25 \pm 0.12)$ as compare to treatment $(3.75 \pm$ $0.04)$ group. Similar finding was reported by Singh et al., (1997) in the dairy cattle. Mastitic milk has low percentage of lactose and after treatment of mastitis with tri-sodium citrate, milk lactose restores to normal composition (Singh et al., 2007). The decrease in milk lactose in affected quarters is probably due to damage of the alveolar epithelial cells.
In conclusion, SFMT proved to be a quick, easy and reliable diagnostic test for SCM. Administration of trisodium citrate recovered the dairy cows from SCM cases. Treated animals found to have reduced SCC, maintained normal milk $\mathrm{pH}, \mathrm{EC}$ and increased milk yield, fat $\%, \mathrm{SNF} \%$, protein $\%$ and lactose $\%$. Hence, the sustainable solution for detection (by SFMT) and control (by TSC) of SCM is a cost effective and easily dispensable option which farmers can easily adopt as a management practice.

\section{Acknowledgement}

The authors are thankful to the Head, ICAREastern Regional Station, National Dairy Research Institute, Kalyani, West Bengal for providing financial support for the study.

\section{References}

$19^{\text {th }}$ livestock census (2012). All India Report. Ministry of Agriculture, Department of 
Animal Husbandry, Dairying and Fisheries, Krishi Bhawan, New Delhi.

Ashworth, V. S., Foster, T. L. and Lucdecke, L. O. (1967). Relationship between CMT reaction and composition of milk from opposite quarters. Journal of Dairy Science 50: 1078.

Bansal, B. K. and Gupta, D. K. (2009). Economic analysis of bovine mastitis in India and Punjab- A review. Indian Journal of Dairy Sciences 62(5): 33745.

Dhillon, K. S. and Singh, J. (2009). Managing chronically mastitic cows. Veterinary Record, 8th ed. In Dhillon, K.S., J. Singh and B.S. Gil. 1989. A new horizon in mastitis treatment. Journal of Research Punjab Agricultural University 26(3): 477-81.

Dhillon, K. S., Singh, T. J., Sodhi, S. S., Sandhu, H. S., Dwivedi, P. N., Singh, J. and Gill, B.S. (1995). Milk bacteriology: Pre and post-trisodium citrate mastitis treatment in buffaloes. Indian Journal of Animal Sciences 65: 9-11.

Dhillon, K.S., Singh, J. and Gill, B.S. (1989). A new horizon in mastitis treatment, Journal of Research Punjab Agricultural University 26: 177-181.

Fleet, I. R., Goode, J. A., Hamon, M. H., Laurie, M. S., Linzell, J. L. and Peaker, M. (1975). Secretary activity of goat mammary glands during pregnancy and onset of lactation. Journal of Physiology 251: 763 .

Garnsworthy, P. C, Masson, L. L, Lock, A. L. and Mottram, T. T. (2006). Variation of milk citrate with stage of lactation and de novo fatty acid synthesis in dairy cows. Journal of Dairy Science 89: 1604-1612.

Hyvonen, P., Haarahiltunen, T, Lehtolainen, $\mathrm{T}$, Heikkinen, $\mathrm{J}$, Isomaki, $\mathrm{R}$ and Pyorala, S. (2010). Concentrations of bovine lactoferrin and citrate in milk during experimental endotoxin mastitis in early- versus late lactating dairy cows. Journal of Dairy Research 77: 474- 80.

Ilie, L. I., Tudor, L, Galis, A. M. (2010). The electrical conductivity of cattle milk and the possibility of mastitis diagnosis in Romania. Veterinary and Medicine Science Works 43: 220-7.

Janzekovic, M., Brus, M., Mursec, B., Vinis, P., Stajnko, D. and Cus, F. (2009). Mastitis detection based on electric conductivity of milk. The Journal of Advances in Mechanical and Materials Engineering 34: 39-46.

Kumar, A. V. H. (2016). A field approach to mastitis control in India. "Collective Experiences" session at the 6th IDF International Mastitis Conference 7-9 September 2016, Nantes, France.

Mbonwanaya, D. Akal, C., Cedden, F. and Bohloli, S. (2016). Tri-Sodium Citrate use in dairy cows and effects on daily milk yield and quality. Journal of Agricultural, Food and Environmental Sciences 68: 34-7.

Mukherjee, J., Chaudhary, M., Dang, A. K. (2017). Alterations in the milk yield and composition during different stages of lactation cycle in elite and non-elite Karan Fries crossbred cows (Holstein Friesian X Tharparkar). Biological Rhythm Research 48: 499-506.

Norberg E, Hogeveen H, Korsgaard IR, Friggens NC, Sloth KHMN and Lovendahl P. 2004. Electrical conductivity of milk: ability to predict mastitis status. Journal of Dairy Science 87: 1099- 1107.

Prakash, V., Siddiqua, B., Yadav, M. P. S., Singh, R. B. and Singh, S. P. (2013). Various factors responsible for sub clinical and clinical mastitis and pharmacotherapeutic role of tri-sodium citrate. Asian-Australasian Journal of Animal Sciences 8(1): 37-39. 
Prakash, V., Yadav, M. and Singh, S. (2010). Effect of Different Treatment of Mastitis in Cow and Biochemical Changes in Their Milk. AsianAustralasian Journal of Animal Sciences 4:202-204.

Prakash, V. and Sharma, N. D. (1994). Effect of Trisodium citrate per as on $\mathrm{pH}$ of milk in cows. Proceedings of 17th Indian Society for Veterinary Surgery Congress at College of Veterinary Science and Animal Husbandry, Mathura.

Reddy, N. K., Gangaiah, M. and Rao, B. K. (2017). Coated tri-sodium citrate minimizes the pathogens and maximizes the milk and milk fat in sub clinical mastitis. Journal of Bio Innovation 6(3): 386-90.

Renu, G, Gupta, M. P. and Kumar, S. (2016). Significance of Milk Citrate Level as an Aid in Diagnosis of Mastitis and Progression of Its Treatment in Bovines. Indian Veterinary Journal 93(4): 29 31.

Sargeant, J. M., Leslie, K. E., Shirley, J. E., Pulkrabek, B. J. and Lim, G. H. (2001). Sensitivity and specificity of somatic cell count and California mastitis test for identifying intramammary infection in early lactation. Journal of Dairy Science 84: 2018-24.

Sarfaraz, I., Yousaf, A., Muhammad, G., Abbas, Z. R., Zafar, M. A. and Ahmad, T. (2009). Evaluation of tri sodium citrate alone and in combination with levamisole $\mathrm{HCL}$ in the treatment of subclinical mastitis in dairy buffaloes. Pakistan Journal of Zoological Supplement 9: 839-43.

Singh, J., Kaur, K. Meenakshi, A., Verma, S., Kumar, H. and Pannu, M. S. (2007). Nonantibiotic treatment of bovine mastitis. Indian Journal of Veterinary Medicine 27: 133-4.

Singh, T., Varindra, J., Singh, S. and Dhillon, K. S. (1997). Effect of Tri Sodium Citrate for Mastitis Treatment on some Milk Constituents in Cows. The Indian Journal of Animal Sciences 67: 10551056.

Sripad, K. (2013). Detection of sub-clinical mastitis and evaluation of different treatment regimens in bovines. Ph.D Thesis. Karnataka Veterinary, Animal and Fishery Sciences University, Bidar, Karnataka, India.

\section{How to cite this article:}

Tripti Kumari, Champak Bhakat, Amit Kumar Singh, Jyotimala Sahu, D.K. Mandal and Choudhary, R.K. 2019. Low Cost Management Practices to Detect and Control Sub-Clinical Mastitis in Dairy Cattle. Int.J.Curr.Microbiol.App.Sci. 8(05): 1958-1964. doi: https://doi.org/10.20546/ijcmas.2019.805.227 